\title{
MENGEMBANGKAN KEMAMPUAN BERBICARA ANAK DALAM MENCERITAKAN KEMBALI DENGAN METODE SHOW AND TELL
}

\author{
Ine Laela ${ }^{1}$, Desiani Natalina Muliasari ${ }^{2}$, Endah Silawati ${ }^{3}$ \\ Universitas Pendidikan Indonesia
}

\begin{abstract}
The study was conducted based on the problem regarding the children's speaking ability in class B1 of Ananda Kindergarten Palasari, Cibiru, Bandung. The study aims at overviewing the children's speaking ability in retelling of what they see and touch by using show and tell method. It involved 9 children and applied Pelton action research method (2010). There were 3 actions and each action carried out 5 steps: problem identification, data collection, action planning, plan activation, and results evaluation (reflection). The study focused on how children retell 3 characteristics of an object. The result shows that the children's speaking ability improved. The data of action 1 shows only $12.5 \%$ of children that was able to retell 3 characteristics of object. It improved in action 2 and action 3. Action 2 shows that there were 50\% of the children and action 3 shows $100 \%$ or all children were able to retell the characteristics of an object. Thus, it is suggested that the show and tell was an alternative method in improving children's speaking ability
\end{abstract}

Keyword: Show and Tell Method, Speaking Ability, Retell Story

\begin{abstract}
Abstrak: Penelitian ini dilatarbelakangi oleh permasalahan mengenai kemampuan berbicara anak yang belum berkembang di kelas B1 KOBER-TK Ananda Desa Palasari Kecamatan Cibiru Kota Bandung. Penelitian ini bertujuan untuk memperoleh gambaran hasil kemampuan berbicara anak dalam menceritakan kembali dengan metode show and tell. Penelitian ini melibatkan sembilan orang anak sebagai partisipan. Penelitian ini menggunakan metode penelitian tindakan dengan model Pelton (2010) yang terdiri dari 3 tindakan, setiap tindakan terdiri dari 5 langkah yang meliputi identifikasi masalah, pengumpulan data, perencanaan tindakan, pelaksanaan tindakan serta penilaian hasil (refleksi). Kemampuan berbicara yang diteliti pada penelitian ini berfokus pada kemampuan anak dalam menceritakan kembali dengan standar keberhasilan yang dicapai pada setiap tindakannya. Hasil penelitian tindakan ini menunjukkan bahwa kemampuan berbicara anak dalam menceritakan kembali benda atau hasil karyanya meningkat dari tindakan 1 hingga tindakan 3. Berdasarkan hasil penelitian, metode show and tell dapat dijadikan sebagai salah satu alternatif dalam mengembangkan kemampuan berbicara anak usia dini.
\end{abstract}

Kata Kunci: Metode Show and Tell, Kemampuan Berbicara Anak, Kemampuan Menceritakan Kembali

\section{PENDAHULUAN}

Pengembangan bahasa pada Pendidikan Anak Usia Dini (PAUD) menjadi sangat penting karena bahasa berfungsi sebagai alat untuk berkomunikasi satu sama lain. Dengan berkomunikasi, manusia dapat menyampaikan ide, gagasan, perasaan dan keinginannya baik secara lisan maupun tulisan. Nurbiana (2010) mengungkapkan bahasa mencakup cara untuk berkomunikasi, pikiran dan perasaan individu yang dinyatakan dalam bentuk

\footnotetext{
${ }^{1}$ Program Studi Pendidikan Guru Pendidikan Anak Usia Dini, Universitas Pendidikan Indonesia, Kampus Cibiru, Email: lailadyne@gmail.com

${ }^{2}$ Universitas Pendidikan Indonesia, Email: desianinm@upi.edu

${ }^{3}$ Universitas Pendidikan Indonesia, Email: endah_silawati@upi.edu
} 
lambang atau simbol, seperti lisan, tulisan, isyarat, bilangan, lukisan maupun mimik yang digunakan untuk mengungkapkan sesuatu. Sehingga kemampuan berbahasa anak usia dini tidak berfokus pada bahasa tulis; membaca dan menulis saja akan tetapi kemampuan anak untuk memahami bahasa lisan: menyimak dan berbicara menjadi perhatian utama. Harapannya adalah dengan memiliki kemampuan bahasa yang baik, anak akan lebih mudah mengekspresikan bahasa dan keaksaran (Permendikbud, 2014) dalam menjalin hubungan sosial yang baik agar dapat berterima di lingkungannya.

Pada penelitian ini kemampuan berbicara anak dalam berbahasa lisan menjadi fokus utama karena bahasa lisan atau bicara menurut Soejtijiningsih (2014) merupakan suatu bentuk dari bahasa yang dilengkapi dengan artikulasi atau katakata untuk menyampaikan suatu maksud atau tujuan. Dalam berkomunikasi, anak usia dini sangat mengandalkan organ bicaranya. Penggunaan bahasa lisan tersebut lebih memudahkan anak usia dini untuk mengekspresikan perasaan dan keinginannya kepada orang lain di lingkungannya. Dengan berbicara, orang di sekitar anak akan lebih mudah memahami apa yang diinginkan dan dirasakan oleh anak sehingga anak lebih mudah diterima oleh orang lingkungannya.

Berdasarkan hasil studi pendahuluan yang telah dilakukan peneliti di KOBER-TK Ananda pada rentang usia 5-6 tahun (kelas B) menunjukkan bahwa kemampuan berbicara anak dalam mengungkapkan ide, pendapat serta gagasannya sendiri belum berkembang. Hal ini terlihat ketika guru meminta anak untuk menceritakan pengalamannya sebelum pergi ke sekolah, rata-rata anak bercerita dengan mengucapkan satu kalimat. Begitu juga ketika guru bertanya tentang sarapan kepada anak satu persatu, terlihat anak cenderung mengikuti apa yang dikatakan temannya. Peneliti juga menemukan bahwa pada saat proses pembelajaran, hanya ada satu orang anak yang berani berbicara dengan cara bertanya kepada guru tentang kegiatan yang dilaksanakan pada hari itu. Oleh karena itu, peneliti menyimpulkan bahwa anak-anak perlu distimulus agar kemampuan berbicara meningkat.

Salah satu metode pembelajaran yang dapat mengembangkan kemampuan berbicara anak dengan menyenangkan adalah metode show and tell. Tilaar (2013) menyebutkan bahwa show and tell merupakan kegiatan berkomunikasi sederhana, metode show and tell adalah suatu metode pembelajaran dengan kegiatan anak menunjukkan benda dan menyatakan pendapat, mengungkapkan perasaan, keinginan maupun pengalaman terkait dengan benda tersebut. Oleh karena itu, peneliti tertarik untuk mengadakan penelitian dengan judul Mengembangkan Kemampuan Berbicara Anak Usia Dini dalam Menceritka Kembali dengan Metode Show and Tell.

\section{Kemampuan Berbicara Anak Usia Dini}

Kemampuan berbicara merupakan salah satu komponen penting dalam keterampilan berbahasa. Berbicara merupakan suatu keterampilan berbahasa yang terus berkembang. Berbicara adalah suatu kemampuan dalam mengucapkan bunyi-bunyi, artikulasi atau kata-kata untuk mengekspresikan, menyatakan atau menyampaikan pikiran, gagasan dan perasaan (Tarigan, 2015; Brown, 2001 ; Harmer 2001). Kemampuan berbicara melibatkan berbagai faktor pendukung. Faktor organ bicara (Guðlaugsdóttir, 2016; Iverson, 2010) berperan dalam proses pengeluaran kata-kata menjadi sebuah bunyi-bunyi serta intonasi. Faktor bahasa berperan dalam memproduksi kata menjadi sebuah kalimat yang didukung oleh faktor kognitif dalam memilah ide, gagasan serta pikiran yang akan disampaikan serta faktor emosi yang mencakup ekspresi diri dalam 
mengungkapkan keinginan dan perasaan kita kepada orang lain.

\section{Metode Show and Tell}

Metode pembelajaran untuk anak usia dini hendaknya menantang dan menyenangkan, melibatkan unsur bermain, bergerak, bernyanyi dan belajar. Ada banyak metode yang bisa digunakan untuk pembelajaran anak usia dini, salah satu diantaranya yaitu metode show and tell. Musfiroh (2011) mengemukakan bahwa metode show and tell adalah sebuah aktivitas bercerita (tell) yang diikuti dengan aktivitas menunjukkan sesuatu kepada khalayak (show). Lebih lanjut Tilaar (2013) menyebutkan bahwa show and tell merupakan suatu kegiatan berkomunikasi sederhana, kegiatan yang mendorong anak untuk menyatakan pendapat, mengungkapkan perasaan, keinginan maupun pengalaman terkait sesuatu atau benda.

Metode show and tell dapat membantu anak untuk mengungkapkan kemampuan, perasaan, dan keinginannya. Dengan metode ini anak dapat menceritakan segala hal yang ingin diungkapkannya. (Isjoni, 2007).

\section{Jenis Show and Tell}

Show and tell dapat diterapkan dengan menunjukkan sesuatu seperti alat permainan baru, hadiah ulang tahun, makanan oleh-oleh dari saudara, perangkat makan, atau semua benda yang dianggap barang baru ataupun menarik bagi anak (Tilaar, 2013). Selain itu Musfiroh (dalam Rahmawati, 2011) menyebutkan lebih rinci bahwa dalam menerapkan metode show and tell, ada berbagai macam jenis show and tell yang dapat diterapkan diantaranya sebagai berikut :

1) Show and tell dengan benda pribadi

2) Show and tell dengan foto atau gambar

3) Show and tell dengan alat atau benda yang istimewa
Metode ini bisa aplikasikan masingmasing ataupun sekaligus, tergantung kecepatan anak melakukan aktivitas.

\section{Pelaksanaan Metode Show and Tell}

Revermann (dalam Mutasi, 2014) menyebutkan langkah-langkah dalam melakukan show and tell adalah sebagai berikut:

1. Anak-anak diberi tahu agar membawa benda favorit yang akan ditunjukkan dan diceritakan di depan kelas

2. Guru memberikan kesempatan kepada anak untuk tampil menunjukkan dan menceritakan benda yang dibawa dari rumah. Saat tampil anak akan menjadi pusat perhatian bagi teman-temannya.

3. Anak-anak yang lain diperbolehkan mengajukan pertanyaan kepada anak yang sedang tampil.

Selain itu Musfiroh (2011) mengemukakan langkah-langkah dalam melakukan kegiatan show and tell, yakni sebagai berikut:

1. Anak membentuk lingkaran di lantai beralas (karpet, tikar dan sejenisnya).

2. Melakukan kegiatan pembuka

3. Melakukan kegiatan inti, di dalam kegiatan inti guru dapat menjelaskan tata cara kegiatan show and tell. Sebagai permulaan guru bisa mencontohkan kepada anak kegiatan show and tell yaitu sebagai berikut :

a. Guru menjelaskan kegiatan yang akan dilakukan oleh anak

b. Guru memperlihatkan benda atau gambar kepada audience

Guru mulai menceritakan benda atau gambar yang dibawanya kepada audience. Jika sudah selesai, beberapa audience dapat mengajukan pertanyaan kepada pembicara

\section{METODOLOGI PENELITIAN}

Desain penelitian yang digunakan dalam penelitian ini yaitu menggunakan model penelitian tindakan yang dikembangkan oleh Pelton (2010). Penelitian tindakan ini 
dilakukan sebanyak tiga kali tindakan. Proses penelitian yang dikembangkan oleh Pelton ini terdiri dari lima langkah pada setiap tindakan meliputi 1) Identifikasi masalah 2) Pengumpulan data 3) Perencanaan tindakan 4) Perencanaan aktivitas 5) Penilaian hasil.

1) Langkah 1 : Identifikasi Masalah

Pada langkah pertama ini peneliti mengidentifikasi masalah yang terjadi di KOBER-TK Ananda. Hasil penelitian menunjukkan bahwa kemampuan berbicara anak dalam mengungkapkan ide, pendapat serta gagasannya sendiri belum berkembang.

2) Langkah $2:$ Pengumpulan Data

Pada langkah ini peneliti mengumpulkan data melalui observasi kemampuan berbicara anak. Pengumpulan data dilakukan untuk memudahkan peneliti dalam merencanakan tindakan yang akan diberikan kepada anak.

3) Langkah 3 : Perencanaan Tindakan

Pada langkah ini peneliti mempersiapkan instrumen penelitian, indikator yang digunakan dalam penelitian, menyiapkan RPPH untuk masing-masing tindakan, menyiapkan tema serta pokok pembahasan yang akan digunakan dan menyiapkan alat-alat penunjang yang dibutuhkan selama proses penelitian.

4) Langkah 4 : Pelaksanaan Tindakan

Dalam pelaksanaan tindakan peneliti mengacu pada Rencana pelaksanaan pembelajaran harian (RPPH) yang menerapkan metode show and tell sebagai acuan yang digunakan oleh peneliti dalam melaksanakan tindakan.

5) Langkah 5 : Penilaian Hasil (Refleksi) Refleksi pada tindakan inimerupakan langkah untuk merefleksi seluruh tindakan untuk menetukan keberhasilan atas tindakan yang telah dilakukan. Jika data yang dihasilkan tidak sesuai dengan tujuan yang ingin dicapai oleh peneliti maka dilakukan refleksi untuk tindakan selanjutnya, namun jika tujuan telah tercapai maka tindakan dicukupkan.

Penelitian tindakan ini dilakukan di kelompok B1 KOBER-TK yang beralamat di jalan Manglayang Sari Desa Palasari Kecamatan Cibiru, Bandung pada tahun ajaran 2018/2019 yang melibatkan sembilan orang siswa dengan rentang usia lima sampai enam tahun sebagai partisipan. Penelitian ini melibatkan guru kelompok B sebagai mitra observer.

Instrumen penelitian yang digunakan adalah lembar observasi dan pedoman wawancara. Lembar observasi berisi segala aktivitas yang guru dan anak lakukan pada proses pembelajara dengan menggunakan metode Show and Tell, dan juga lembar observasi kemampuan berbicara anak ketika menceritakan kembali dengan mengungkapkan 3 ciri. Selanjutnya pedoman wawancara disusun untuk menggali informasi baik dari siswa maupun guru sebagai mitra observer. Pedoman tertulis tentang wawancara, pengamatan, atau daftar pertanyaan yang dipersiapkan untuk mendapatkan informasi dari responden (Gullo, W, 2002). Peneliti juga menggunakan catatan lapangan untuk menuliskan kejadiankejadian yang terjadi pada saat metode show and tell diterapkan di kelas diluar rencana yang sudah dibuat.

Pada penelitian ini indikator keberhasilan ditetapkan $80 \%$ dari jumlah anak mampu mengungkapkan kembali. Menurut Aqib, dkk. (2009) nilai keseluruhan terpenuhi jika nilai kriteria ideal ketuntasan yaitu $80 \%$. Pada penelitian ini kriteria keberhasilan yang ingin dicapai yaitu mampu menceritakan kembali benda atau hasil karya dengan menyebutkan 3 ciri benda. Analisis data lebih bersifat kualitatif karena peneliti menggambarkan kemampuan juga proses pembelajaran secara detil dan meliputi beberapa tahap reduksi data, penyajian data (display data) penarikan kesimpulan. Analisis data kuantitatif sederhana ditambahkan pada penelitian ini untuk 
menguatkan analisis data kualitatif (Pelton, 2010) menggunakan persentase

\section{HASIL PENELITIAN DAN PEMBAHASAN}

Pada tindakan 1, pembelajaran dilaksanakan dengan tema "binatang". Pada saat melakukan show and tell, guru telah menyediakan benda yang akan ditunjukkan dan diceritakan oleh anak di depan kelas. Benda tersebut terdiri dari mainan- mainan berbentuk binatang yang terdiri dari sembilan macam binatang yaitu zebra, ular, kura-kura, macan, singa, burung kakatua, buaya, unta dan gajah. Guru memberi contoh kepada anak untuk melakukan kegiatan show and tell dengan salah satu mainan tersebut. Setelah itu, anak-anak memulai kegiatan show and tell dengan mengambil satu benda yang ada pada kotak mainan secara bergiliran untuk diceritakan di depan temantemannya. Setelah itu, anak-anak diberi waktu oleh guru untuk bermain dengan mainannya tersebut agar anak siap untuk bercerita di depan teman-temannya.

Ketika aba-aba bercerita telah dimulai anak-anak mulai memperlihatkan benda yang dibawa dan bercerita secara satu persatu di depan teman-temannya. Pada saat menunjukkan (show) mainan di depan teman-temannya anak terlihat malu-malu. Pada saat anak menceritakan (tell) mainan di depan teman-temannya, anak-anak terlihat kebingungan dan perlu stimulus dengan cara memberikan pertanyaan agar anak mau berbicara di depan teman-temannya. Saat bercerita di depan teman-temannya, rata-rata anak hanya mampu mengucapkan satu kalimat. Setelah itu anak diminta untuk menceritakan kembali, cerita yang telah diucapkan oleh temannya.

Tindakan kedua, pembelajaran bertemakan "kendaraan" dengan topik pembahasan "kendaraan yang ada di darat". Pada saat melakukan kegiatan show and tell, guru telah menyediakan benda yang akan ditunjukkan dan diceritakan oleh anak di depan kelas.
Benda tersebut terdiri dari mainanmainan berbentuk kendaraan yang terdiri dari gambar mobil, motor, becak bis, sepeda dan kereta. Pada tindakan kedua, guru tidak memberi contoh kepada anak untuk melakukan kegiatan show and tell dengan mainan-mainan tersebut. Setelah itu, anak-anak memulai kegiatan show and tell dengan mengambil satu benda yang ada pada kotak mainan secara bergiliran untuk diceritakan di depan teman-temannya.

Pada tindakan kedua ini guru memadukan metode show and tell dengan kegiatan yang lain yaitu mewarnai gambar kendaraan dengan menggunakan cotton buds. Anak harus mengambil gambar yang akan diwarnainya dengan mainan yang telah dipilih oleh anak sebelumnya. Karya yang telah dibuat oleh anak tersebut ditunjukkan (show) dan diceritakan (tell) didepan teman-temannya. Setelah kegiatan mewarnai gambar kendaraan menggunakan cotton buds selesai dilaksanakan, anak-anak bersiap dengan cara mendengarkan aba-aba dari guru untuk mulai bercerita. Ketika aba-aba bercerita telah dimulai anak-anak mulai menunjukkan hasil karyanya dan bercerita secara satu persatu di depan temantemannya. Pada saat menunjukkan (show) hasil karyanya di depan teman-temannya anak-anak terlihat antusias dan percaya diri. Pada saat anak menceritakan (tell) hasil karyanya di depan teman-temannya, anak-anak sudah berani menyapa temantemannya namun anak masih terlihat kebingungan dalam menceritakan hasil karyanya. Saat bercerita di depan temantemannya rata-rata anak mampu mengucapkan dua sampai tiga kalimat. Setelah itu anak diminta untuk menceritakan kembali, cerita yang telah diucapkan oleh temannya pada tindakan 2 ini anak mampu menceritakan kembali benda atau hasil karya dengan menyebutkan dua sampai tiga ciri benda.

Tindakan ketiga, pembelajaran bertemakan "Lingkunganku" dengan topik pembahasan "Keluargaku". Pada 
saat melakukan kegiatan show and tell, guru tidak lagi menyediakan benda yang akan ditunjukkan dan diceritakan oleh anak di depan kelas. Akan tetapi, guru telah meminta anak untuk membawa foto keluarga. Foto keluarga tersebut akan di hias dengan bahan-bahan yang telah disediakan seperti kertas warna, stik es krim, cat warna, bintang-bintang dan manik-manik. Karya yang telah dibuat oleh anak tersebut akan ditunjukkan (show) dan diceritakan (tell) didepan teman-temannya. Setelah kegiatan menghias foto keluarga selesai dilaksanakan, anak-anak bersiap dengan cara mendengarkan aba-aba dari guru untuk mulai bercerita. Ketika aba-aba bercerita telah dimulai, anak-anak mulai menunjukkan hasil karyanya dan bercerita secara satu persatu di depan temantemannya. Pada saat menunjukkan (show) hasil karyanya di depan teman-temannya anak-anak terlihat antusias, semangat dan penuh percaya diri. Pada saat anak menceritakan (tell) hasil karyanya di depan teman-temannya, anak-anak sudah berani menyapa teman-temannya dan sangat percaya diri saat bercerita tentang keluarganya melalui foto keluarga yang telah dibawanya.

Pada tindakan ketiga ini mengalami perubahan ke arah yang lebih baik. Saat bercerita di depan teman-temannya ratarata anak hanya mampu mengucapkan tiga sampai empat kalimat. Setelah itu anak diminta untuk menceritakan kembali, cerita yang telah diucapkan oleh temannya pada tindakan 3 ini anak mampu menceritakan kembali benda atau hasil karya dengan menyebutkan tiga sampai empat ciri benda.

Berdasarkan data di atas, penerapan metode show and tell dapat mengembangkan kemampuan berbicara anak usia dini. Berikut persentase kemampuan berbicara anak usia dini dalam mengucapkan kalimat dari tindakan 1 sampai dengan tindakan 3 .

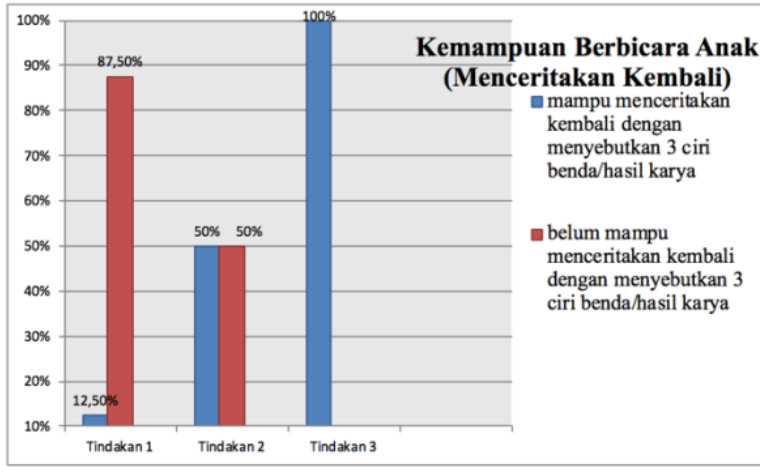

Gambar 1.1 Persentase Kemampuan Berbicara Anak Usia Dini dalam menyusun kalimat Ketika Penerapan Metode Show and Tell

Berdasarkan gambar 1.1 dapat diketahui bahwa perkembangan kemampuan berbicara anak usia dini dalam menceritakan kembali benda atau hasil karya dengan menyebutkan 3 ciri benda tersebut (nama, warna, bentuk dan ukuran benda) ketika penerapan metode show and tell yang ditandai dengan grafik berwarna biru, persentase kemampuan berbicara anak sebesar 12,5. Pada tindakan 1 ini anak hanya mampu menceritakan kembali benda atau hasil karya dengan menyebutkan satu ciri benda seperti yang dilakukan oleh $\mathrm{Rz}$ " hai teman teman.. Ini mainan zebra yang dibawa oleh Fr warnanya hitam dan putih ". Pada tindakan 2 tingkat keberhasilan anak dalam menceritakan kembali sebesar 50\%, seperti cerita yang sudah diungkapkan oleh anak Ra dan Ki.

Ra: " teman teman.. Ini mainan Na ini bis ya.. Bis tayo warnanya biru bisnya kecil ih."

$\mathrm{Ki} "$ hallo teman teman ini mainan punya $N d$, sepedanya bagus warnanya putih tapi di belakangnya ada becaknya. Ini sepeda atau becak bu guru?"

Sedangkan pada tindakan 3 kemampuan anak dalam menceritakan kembali ketika penerapan metode show and tell sebesar $100 \%$. Pada tindakan 3 anak terlihat signifikan kemampuan menceritakan kembali benda atau hasil karya dengan menyebutkan tiga sampai empat ciri benda sebagai contoh berikut hasil dari anak Hy dan $\mathrm{Nd}$

Hy : teman teman.. Ini foto keluarganya $R v, R v$ sayang semuanya. Ini ayah $R v$ ini ibunya $R v$ ini kakanya Rv. Ini Rv hehehe " 
$\mathrm{Nd}$ " ini keluarga Hy. Hy difoto ini pake kerudung. Ada ayahnya ada mamanya ada kakaknya ada adik bayi".

Pada tindakan 3 terlihat bahwa perkembangan anak meningkat secara signifikan. Pada Tindakan satu anak hanya mampu menceritakan kembali dengan menyebutkan satu ciri saja tetapi pada tindakan 3 sudah mampu menceritakan kembali dengan menyebutkan tiga cerita.

\section{KESIMPULAN}

Kemampuan berbicara anak usia dini di Kober-TK Ananda terlihat perkembangannya dengan signifikan. Hal ini terlihat dari jumlah anak yang berkembang kemampuan menceritakan kembali dari mulai tindakan 1 sampai tindakan 3. Kemampuan berbicara anakpun dipengaruhi oleh stimulus yang dilakukan oleh guru. Kemampuan berbicara anak hingga mampu mengungkapkan 3 ciri bahkan lebih juga dipengaruhi oleh faktor latihan yang dilakukan oleh guru dari tindakan 1 hingga tindakan tiga. Dengan demikian, maka dapat ditarik kesimpulan metode show and tell dapat mengembangkan kemampuan berbicara anak usia dini dalam menceritakan atau mengungkapkan kembali benda berdasarkan tiga ciri benda yang melingkupinya.

\section{DAFTAR PUSTAKA}

Brown, H.D. (2001). Teaching by Principles: An Interactive Approach to Language Pedagogy. New York: Longman.

Gullo, W. (2002). Metodologi Penelitian. Jakarta: PT. Grasindo.

Isjoni. (2007). Cooperative Learning Efektivitas Pembelajaran Kelompok. Bandung: Alfabeta

Iverson, Jana M. (2010). Developing language in developing body: the relationship between motor developmentand language developmen. Journal of Child Language, 37 (2), 229-261.
Guðlaugsdóttir, E.B. (2016). Children's First Langauge Acquisition: What is needed for Children to Acquire Language. Unpublished BA Essay. Haskoli Island

Harmer, J. (2001). The Practice of English Language Teaching. Third Edition. England: Longman.

Madyawati, L. (2016). Strategi Pengembangan Bahasa Pada Anak. Jakarta: Kencana.

Musfiroh, T. (2011). Show And Tell Edukatif untuk Pengembangan Empati Afiliasi-Resolusi Konflik, dan Kebiasaan Positif Anak Usia Dini. Jurnal Kependidikan, 41, 2, $129-143$

Nurbiana, D. (2010). Metode Perkembangan Bahasa. Jakarta: Universitas Terbuka.

Pelton, R. (2010). Action Research for Teacher Candidates: Using Classroom Data to Enchance Instruction. United States Of America: Librabry of Congress Catalogin-in-Publication Data.

Permendikbud. (2014). Standar Nasional Pendikan Anak Usia Dini . Jakarta: Kementerian Pendidikan dan Kebudayaan

Rahmawati, S. (2016). Pengaruh Bermain Show and Tell terhadap Kemampuan Berkomunikasi Lisan Anak Usia Dini Kelompok B di PAUD Mitra Terpadu Natar Lampung Selatan. (Skripsi). FKIP, Universitas Lampung, Bandar Lampung.

Tarigan, H. (2015). BERBICARA: Sebagai Suatu Keterampilan Berbahasa. Bandung: Angkasa Bandung.

Tilaar, H. (2013). Media Pembelajaran Aktif. Bandung: Nuansa Cendekia.

Mutasi, O. (2014). Meningkatkan Percaya Diri melalui Metode Show and Tell pada Anak Kelompok A Tk Marsudi Putra, Dagaran, Palbapang, Bantul, Yogyakarta. (Skripsi). FIP, Ilmu Pendidikan, Universitas Negeri Yogyakarta, Yogyakarta. 